rentimento

\title{
hef.
istoi
}

orle III

Thor

do pean a noste

wo himinoto

im intuin trlos

neo antens

atritegas do ar; ida, ride horizmte. lim, trite, mento iluminoto dentro.

corrsio, ly rento.

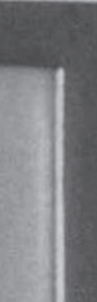




\section{Lupe e paisagem}

\section{Luís Milanesi}

palavras-chave: ensino; história da ECA-USP;

ditadura militar: militância estudantil

Keywords: teaching; the history of ECA-USP; military dictatorship; student militancy
Trata-se de um relato pessoal em que o autor rememora sua convivência com Lupe Cotrim, de quem foi aluno na então recém-fundada Escola de Comunicações, no conturbado período da ditadura militar.

In this personal report, the author recollects his acquaintanceship with Lupe Cotrim, who was his professor at the School of Communications, then newly founded, in the troubled period of Brazilian military dictatorship. 
No ano de 1968 aprendi mais na prática do que na teoria. Isso por um motivo: o período de aulas foi tumultuado por uma série de ações de protesto, além de uma greve que durou meses na USP, reflexo local do que ocorria na França e em outros países. Como calouro da recém-fundada Escola de Comunicações Culturais, tive a experiência radical de incorporar-me aos que se opunham ao regime militar e suas ações que afrontavam valores caros como democracia, liberdade e demais itens da relação de direitos humanos... Essa situação tensa, de perigos constantes, fez os universitários da época terem uma experiência concreta de participação de risco. Com tantos desafios pela frente, os estudantes viveram, na prática, a oportunidade de dizer o que era necessário, manifestando-se fortemente como cidadãos em defesa dos seus direitos fundamentais num tempo claro de guerra. O clima entre alunos e professores era tenso, mistura de medo e indignação.

Com a polícia no calcanhar e o DOPS como um fantasma onipresente, nós, os alunos, não tínhamos muito entusiasmo com as aulas que tivemos até maio. Com o país tumultuado e as constantes ameaças pairando sobre a cabeça de cada um, não era possível embarcar nas aulas teóricas de uma Escola que, ainda, não sabia bem o que ensinar. Entre disciplinas como História da Arte, Cultura e Civilização no Brasil e História da Civilização Contemporânea aparecia algo mais preciso: Pensamento Filosófico e Estética. A primeira era ministrada por uma professora argentina chamada Maria Scuderi. A segunda, puxo pela memória, estava sob a responsabilidade do Prof. Carrato. A terceira era conduzida pelo jovem Professor Virgílio Noya Pinto. E a última, por uma uspiana, formada em Filosofia e mulher de outro filósofo e professor: José Arthur Giannotti. Nome curto e marcante: Lupe Cotrim. Sabíamos pouco de sua carreira, inclusive que era bibliotecária - a área que me interessava. E que escrevera livros de poesia.

As aulas eram dadas no prédio hoje denominado "Reitoria Velha". A ECA nasceu às pressas e não havia onde abrigá-la. Resolveu-se que sua sede provisória seria o prédio onde despachava o reitor Mário Guimarães Ferri e de onde foi, praticamente, despachado pelos insurretos juvenis, que viam nele, de forma injusta, um agente da ditadura militar. Nesse prédio e no chamado barracão B-9 eram dadas as aulas que, de uma forma geral, não recebiam dos alunos nenhuma prova de apreço. Mesmo porque os assuntos externos mobilizavam mais do que as teorias da comunicação.

Tivemos dois meses de aula e só retornamos em dezembro, depois do Ato Institucional de 13 de dezembro, curiosamente, dia de Santa Luzia, padroeira dos que sofrem dos males da visão. De maio em diante a Escola realizou uma série de atividades, além das assembleias 
e passeatas gigantescas, confrontos violentos, reunindo intelectuais, artistas de várias áreas. Nesse período passaram pela Escola figuras notáveis: Edgard Morin, Glauber Rocha, Roberto Rosselini... O Bloco B-9, tomado, era a sede das atividades.

A Lupe eu a vi, primeiramente, na sala de aula da Reitoria, um espaço em forma de anfiteatro. Os professores ficavam sobre um tablado à frente de uma lousa. Lupe escrevia muito com o giz enquanto citava Marcuse, um best-seller da época, Sartre, Nietzsche, Engels, Marx... A imagem mais forte que me ficou foi essa: uma figura esguia, cabelos negros, olhos verdíssimos. E tão bonita que todos nós corríamos o risco de menos ouvi-la e mais contemplá-la.

Depois de algumas aulas, eu que nunca lera antes filósofos não mais achava a ponta da meada. E isso ocorria também com outros alunos. E já naquela época havia o grito de guerra que se firmou na ECA: "eu não vim aqui para filosofar". E cada um dizia o que desejava fazer na Escola de Comunicações Culturais (teatro, cinema, jornal...). Eu não pensava assim, mas também não estava feliz com tantas teorias desconectadas. Especificamente as aulas da Lupe assustavam, pois a maioria não dava conta de absorver os discursos oceânicos que saltitava pelos séculos - de Sócrates a Sartre, de Aristóteles a Heidegger...

Um episódio ficou na memória com clareza: no fim de uma aula, à beira de pedir clemência, um indulto prévio, solicitei uma conversa pessoal. Na época poucos alunos tinham carro e Lupe sempre, ao sair, dava carona. Fomos conversando até o seu provável "fusca". Abriu a porta, entramos e, ao dar a partida, ouviu assustada o meu protesto, pois eu não iria sair da Cidade Universitária. Desligou o carro e passou a ouvir minha lamúria. Previdente, como sempre fazia, escrevi numa tira de papel o que eu desejava conversar com ela. Arrolei alguns tópicos. O último era algo como "estamos perdidos". Mas a conversa fluiu de forma tão agradável que me esqueci do papelzinho e do meu papel de vítima da filosofia. Muito agradecido abri a porta do carro para sair, e Lupe cobrou: "falta o último item”. Devo ter ficado roxo e, encabulado, desconversei.

De fato, tinha meus problemas com a Filosofia. Fui bem numa prova escrita, onde podia disfarçar minha ignorância sobre Hegel, mas na prova oral era impossível esconder que nada sabia sobre Kant. Resultado: minha nota final foi um suficiente 5,0. O que me marcou nessa provação foi um detalhe: na prova escrita que me salvou, às margens do meu texto Lupe fez comentários. Isso me foi marcante e me fez, depois, como professor, ler e comentar os trabalhos de meus alunos, reproduzindo a ação e esperando que se sentissem individualizados, como me senti com os comentários nas margens do meu tosco texto. 
Há outro episódio que ocorreu no edifício em construção e que, hoje, é o prédio principal da ECA. Os alunos promoveram uma exposição de arte ali. Na época me dedicava a espalhar fios de piche sobre placas de aglomerado de madeira, formando desenhos abstratos preenchidos com guache e recobertos por cola pva. Mostrava os meus trabalhos, quando criou-se uma discussão: arte ou artesanato? Lupe, acatadíssima, disse: "é arte”. A discussão não faz mais sentido, mas naquele momento eu me senti introduzido no panteão dos artistas... Acho que foi a última vez que vi a Lupe.

Da presença de Lupe na ECA e de outros professores destaco Paulo Emílio, do qual ela era muito próxima - me ficou uma certeza. Segundo algumas teorias, a ECA, por ter sido fundada graças ao empenho pessoal de Dona Edi, mulher do ex-Reitor Gama e Silva, depois ministro da Justiça do marechal Costa e Silva, fora engendrada nos laboratórios militares para garantir a formação de comunicadores isentos da influência "comunista". Pelo perfil inicial da ECA - uma instituição em todos os sentidos nova -, pela participação forte dos alunos, pelo perfil de parte de seu corpo docente inicial, ressaltando-se a figura inquieta de Lupe, essa intenção da ditadura, se houve, não se concretizou. A Lupe era o oposto do que nos chegava da força militar centrada em Brasília e espalhada como terror pelo País. Com suas aulas, a sua poesia e apreço dos alunos, ela era o oposto desse tempo, depois denominado "anos de chumbo". A Lupe foi a cara da ECA inicial.

Maio de 2010

Luís Milanesi é professor da Escola de Comunicações e Artes da USP, onde se formou e da qual foi diretor entre 2005 e 2008. Autor, entre outros livros, de O paraíso via Embratel e A casa da invenção. Criador e coordenador de duas redes sociais na internet: "Em busca da biblioteca perdida" e "Políticas Culturais no Brasil". Aluno de Lupe Cotrim na atual ECA, escreveu o artigo "O último tópico" sobre a professora-poeta. 
